\title{
Determinants of credit constraints and its impact on the adoption of climate change adaptation strategies among rice farmers in South-West Nigeria
}

\author{
T. O. Ojo ${ }^{1,2^{*}}$ and L. J. S. Baiyegunhi
}

${ }^{*}$ Correspondence:

ojotemitope70@yahoo.com

2 Department of Agricultural Economics, Obafemi

Awolowo University, Ile-lfe, Nigeria

Full list of author information is available at the end of the article

\begin{abstract}
Interventions on climate change adaptation strategies, involve capital outlays, mostly constrained in supply in developing nations. This study analysed the impact of credit constraints on climate change adaptation strategies among smallholder rice farmers in South-West Nigeria. The nexus between systems of credit constraints and choice of climate change adaptation strategies was estimated using Generalized Method of Moments with Instrumental Variable (IV-GMM) and the seemingly unrelated regression (SUR) model. A principal component analysis (PCA) was used to reduce the multidimensionality of the adaptation strategies and the loading with the highest eigenvalue was chosen and renamed as an improved technology. The results of the study show that risk credit-constrained smallholder rice farmers are less likely to adopt climate change adaptation strategies. The quantitative analysis from this study also points to the fact that age of the household, source of credit, and distance to the source of credit, interest rate, access to extension and climate information were the determinants of credit constraint amongst the smallholder rice farmers in South-West Nigeria. Considering the nexus between climatic factors and credit constraints as noted in this study, increasing awareness about how the credit market works and information on the provision of climate change can help farmers to better adapt to climate change. Therefore, it is recommended that the government frame an agriculture credit policy addressing the issues of smallholder farmers, particularly in areas that are vulnerable to climate change. The income from non-farm activities can be reinvested into farm operations to improve farmers' adaptive capacity and subsequently increase productivity. It could also be recommended that policies enhancing and strengthening institutional support may also be valuable in augmenting the adaptation strategies of smallholder farmers. A necessary addition should be developed to the assistance already being provided under Nigeria Incentive-Based Risk Sharing System for Agricultural Lending (NIRSAL) in the form of loan guarantees and other risk-sharing incentives, such as a regulatory environment that supports the modern contractual obligations that are characteristic of well-functioning agricultural financing.
\end{abstract}

Keywords: Credit constraint, Climate change, Adaptation strategies, IV-GMM and SUR 


\section{Background}

Empirical literature has shown the negative impact of climate change on the agricultural sector, and most vulnerable to this impact are farmers in developing countries (Mulwa et al. 2017). Studies by Knox et al. (2012) and Sarker et al. (2014) showed that an adequate increase in temperature will pose an adverse impact on productivity of main staple crops such as rice, maize and wheat. As empirically posited in literature, the adoption of adaptation strategies therefore remains an important option in mitigating the effect of climate change, and also addressing its prevailing challenges on rice production (Huq et al. 2004; Deressa et al. 2009; Seo 2011). This calls for an enhanced innovative adaptive ability, the effects of which are important in improving agricultural production (Di Falco and Veronesi 2013). In spite of their importance in climate risk mitigation and food security (Kassie et al. 2013), the adoption of adaptation strategies remains too low (Holden et al. 2003).

According to Ellis (2000), the relationship between climate change and credit demand attests to the view that financial resources can help poor smallholder farmers harness intrinsic potential required for resilience against production risks. Agricultural finance involves lending money to farmers to stimulate the productivity of limited farm resources (Adegeye and Dittoh 1985; Muniraj 1987). Eswaran and Kotwal (1990) suggested that the provision of agricultural credit makes additional capital available for improving the level of households' productive and physical capital. Among many factors that limit investments in agriculture, credit constraints, credit market imperfections and stringent conditions for credit accessibility are strong contributors in making an investment in agriculture, particularly climate change adaptation strategies unattractive (Holden et al. 2003).

According to Jaffee (1971), credit constraint is the difference between the quantity of credit demand and credit supply at the concessionary interest rate. Empirical studies have looked at different aspects of credit constraints, stemming from quantity constraint (Petrick 2004) to risk constraint and price constraint (Doan 2010). With the exception of Khantachavana et al. (2011) and Olomola and Gyimah-Brempong (2014), consideration of all the various forms of credit constraints in a study is very scarce. Credit quantity constraint means total rejection, or receiving less than the amount requested because of inability of the borrowers to meet the collateral requirements of the lending institutions. Credit price constraints ensue as a result of high transaction costs involved in processing, monitoring and recovery of credit by lenders, while credit risk constraints arise in conditions where prospective borrowers are credit averse as a result of fear of losing the assets pledged as collateral (Boucher et al. 2008). Farmers who are either price or riskconstrained, as compared to their quantity-constrained folks, willingly object to obtain credit despite their agricultural production being feasible in viable credit markets.

Financial resources can potentially form one of the key strategies to both expanding and strengthening risk mitigating strategies, particularly in the presence of an increasing threat of climate change. However, the direct role of access to credit in mitigating against climatic risks, and the nature of credit constraints and their differing impacts on specific climate change adaptation strategies have not been fully examined. Evidence on the specific links between credit constraints and choice of adaptation strategies are mostly mixed (Dinopoulos et al. 2017). An analysis of the impact of credit constraints on 
adaptation to climate change is pertinent. Many studies have shown the positive impact of climate change adaptation strategies household food productivity (Di Falco et al. 2011; Ngigi et al. 2017) in developing countries. However, there is a dearth of study on how credit constraints affect the choice of climate change adaption strategies. The choice of adaptation strategies and their likely variance responsiveness to financial constraints, in particular, has not been fully harnessed, especially within a cross-sectional framework.

Understanding the determinants of credit constraints and its impact on adoption of adaptation strategies to climate change among smallholder farmers is particularly relevant as panacea to implementation of climate change adaptation strategies (Leclère et al. 2013). This study therefore investigates the determinants of smallholder rice farmers' credit constraints and their impact on adaptation strategies to climate change. The remainder of this paper consists of the following: the analytical framework used for this study, discussions on the study area, survey design and method of data collection, the empirical results and discussion and lastly, the conclusion and policy implication of the study.

\section{The study area and method of data collection}

The study was carried out in the southwestern part of Nigeria, consisting of the Lagos, Ogun, Oyo, Osun, Ondo and Ekiti States. The area lies between the longitude $2^{0} 31^{1}$ and $6^{0} 00^{1} \mathrm{E}$ and the latitude $6^{0} 21^{1}$ and $8^{0} 37^{1} \mathrm{~N}$, with a total land area of about $77,818 \mathrm{~km}^{2}$. It is bound in the east by the Edo and Delta States, in the north by the Kwara and Kogi States, in the west by the Republic of Benin and in the south by the Gulf of Guinea. The climate of South-West Nigeria is tropical in nature and it is characterized by wet and dry seasons. The mean temperature ranges between $21{ }^{\circ} \mathrm{C}$ and $34{ }^{\circ} \mathrm{C}$, while the annual rainfall ranges between $150 \mathrm{~mm}$ and $3000 \mathrm{~mm}$. The wet season is associated with the southwestern monsoon wind from the Atlantic Ocean, while the dry season is associated with the northeastern trade wind from the Sahara Desert. The vegetation in SouthWest Nigeria is made up of fresh water swamp and mangrove forest at the belt, the low land in forest stretching inland to the Ogun and part of the Ondo States, with the secondary forest stretching towards the northern boundary by the derived and southern Guinea savannas (Agboola 1979). According to Ayanlade et al. (2017), one of the challenges of agricultural production in South-West Nigeria is the frequent complete loss of crops due to adverse weather conditions or pests. Changing weather patterns or extreme weather events, such as floods or droughts, have impacted negatively agricultural production in this region. These drought periods are indications of the great variability of climate and the most serious effects of which are usually felt at the drier margins of agricultural zones or in the regions occupied primarily by smallholder farmers.

A multistage sampling technique was used to select the respondents for the study. The first stage involved a typical case-purposive selection of three states, Ekiti, Ondo and Osun states located in the same agro-ecological area. In the second stage, four local government areas (LGAs) were then selected from each state, based on the predominance of smallholder rice farmers in these areas, using a typical case-purposive sampling. In the third stage, five villages were randomly selected from each of the four LGAs. Following Tesfahunegn et al. (2016), at 95\% confidence level and 5\% margin of error, the sample size for the study was determined using the sample determination formula as described 
by Cochran (1977), allowing for six smallholder rice farmers to be selected from each of the 5 villages earlier selected to give 360 respondents interviewed for the study.

In addition, the study also conducted focus group discussions (FGDs) to engender information on the farmers' knowledge of climate change, its related hazards, susceptible groups in the area and existing adaptation strategies. Twelve FGDs were conducted in each of the LGAs, with the participation of at least 10 farmers from each LGA. Information sourced from the FGDs helped in re-structuring of the questionnaire. In line with the climate variables, monthly averages of precipitation and temperatures from 1970 to 2014 was specifically obtained from the Nigeria Meteorological Agency (NIMET) at Oshodi in Lagos, Nigeria, and the International Institute for Tropical Agriculture (IITA) in Ibadan, Nigeria.

\section{Analytical and estimation framework}

Analysing the impact of credit on different adaptation strategies by simple regression would lead to bias, because households' credit market participation decisions are likely to be non-random if those who have access to credit have systematically different characteristics from those who are credit-constrained. For example, households with more collateral resources, or those who possess better individual skills, ability and motivation may have better access to credit, while those with fewer resources and weak networks are more likely to be credit-constrained. Such factors may influence both access to credit and choice of adaptation strategies, resulting in inconsistent estimates of the effect of credit constraints on the adaptation activity. In such instances, an appropriate model of analysis requires accounting for possible selection bias.

Furthermore, different technologies to mitigate agricultural production shocks are adopted by smallholder farmers. The implication of this is that adoption decision is intrinsically multivariate, and economic information about interdependent and simultaneous adoption decisions would be excluded if univariate modelling is employed (Dorfman 1996). Therefore, the econometric approach involves a two-stage estimation technique. In the first stage, the determinants of credit constraints are estimated by using the seemingly unrelated regression (SUR) model, whereby the predicted values of different credit-constraint categories are obtained.

In the second stage, a generalized method of moments with instrumental variables (IV-GMM) was employed to analyse the impact of credit constraints on the choice of adaptation strategies, with predicted values of credit variables included as selectivity correction terms from the first stage. The decision of the farmers to adopt or not climate change adaptation strategies is not voluntary and may perhaps be based on individual self-selection. Smallholder farmers who adopted may have systematically different characteristics from the farmers who did not adopt, and they may have decided to adopt based on expected benefits. Following Asfaw et al. (2016) and Baiyegunhi et al. (2010), unobservable characteristics of smallholder farmers might affect both the adoption decision of climate change adaptation strategies and credit constraints, resulting in inconsistent estimates of the adoption on climate change adaptation strategies. It is therefore imperative to explicitly account for such endogeneity using an instrumental regression technique that assumes a joint normal error distribution, as posited by Di Falco et al. (2011). 
The additional variable in the impact of credit constraints on climate change adaptation strategy equation serves as an instrumental variable to control for unobservable factors. As posited by Baiyegunhi et al. (2010), the choice of instruments is premised on the assumption that a variable that is correlated with the credit constraints, but not with the error term of adoption of climate change adaptation strategies model. Hence, access to climate change information was used as the potential instruments. Following Abdulai and Huffman (2014), presence of endogeneity was corrected using contacts with extension agents and membership of farmers in farmers' association as instrumental variables in the model. As posited by Wooldridge (2003) and Baum et al. (2003), the moment conditions of IV-GMM are the same as normal instrumental variable regression, the random heteroscedasticity and intra-cluster correlation was accounted for with the weighting matrix of GMM estimator. The GMM estimator is consistent and asymptotically efficient in the presence of heteroscedasticity.

\section{Econometric specifications}

The SUR model is used to analyse the determinants of credit constraints among smallholder rice farmers in the study area. This approach had been used in similar studies (Khantachavana et al. 2011; Nilakantan et al. 2013). Bearing in mind the likelihood of formal lenders to discriminate against smallholder farmers in their credit activities, these farmers' socioeconomic characteristics will undoubtedly influence their creditconstraint status, simply put, the variables that affect quantity constraint can also affect risk constraint and pricing constraint, however, the impact would be diverse. The model was therefore specified by cross-equation correlation among the error terms, hence the use of SUR.

According to Asfaw et al. (2016), a correlation coefficient with a positive sign is consistent with the unobservable heterogeneity in the tendency to discriminate the smallholder rice farmers. Conversely, a coefficient with a negative sign is in consonance with the interpretation that factors influencing smallholder rice farmers' likelihood of being less credit-constrained. As implicitly expressed in Eq. 1, the degree to which a rice farmer is credit-constrained is indicated by an index $y_{i}^{*}$, which is a latent variable, as the amount of a household's excess credit demand cannot be directly observed (Foltz 2004):

$$
y_{i}^{*}=X_{i}^{*} \beta_{i}+\varepsilon_{i} \quad i=1 \ldots N
$$

where, $y_{i}$ the observed variable equals 1 if $y_{i}^{*}>0$, when a farmer is credit-constrained (quantity, risk and pricing constraint) and 0 if $y_{i}^{*} \leq 0 ; X_{i}$ is a vector of covariates; $\beta_{i}$, parameters to be estimated; while $\varepsilon_{i}$ is the error term. The three credit-constraint conditions are modelled in the analysis, namely quantity constraint, risk constraint, and pricing constraint. The equations for the three credit-constraint conditions are specified as follows:

$$
\begin{aligned}
& y_{1 i}=\delta_{i} X_{i}+v_{i} \\
& y_{2 i}=\varpi_{i} X_{i}+\psi_{i}
\end{aligned}
$$




$$
y_{3 i}=\theta_{i} X_{i}+\vartheta_{i}
$$

where $y_{1 i}$ is a binary variable which takes a value of 1 for a quantity-constrained farmer $i$ and 0 if otherwise; $y_{2 i}$ has a value of 1 for a risk-constrained farmer $i$ and 0 if otherwise; $y_{3 i}$ has a value of 1 for a price-constrained farmer $i$ and 0 if otherwise; $X_{i}$ represents a vector of explanatory variables; $\delta_{i}, \varpi_{i}$ and $\theta_{i}$ are coefficients to be estimated; and $v_{i}, \psi_{i}$ and $\vartheta_{i}$ are random error terms.

In this regard, the stacked model with respect to expression $X$, where $\sum$ represents the variance and covariance matrix in the model, for the $i$ th observation, $N \times N$ the covariance matrix of the disturbance is calculated by:

$$
\left|\begin{array}{c}
y_{1} \\
y_{2} \\
y_{N}
\end{array}\right|=\left[\begin{array}{ccc}
X_{1} & 0 & 0 \\
0 & X_{2} & 0 \\
0 & 0 & X_{N}
\end{array}\right]\left|\begin{array}{c}
\beta_{1} \\
\beta_{2} \\
\beta_{N}
\end{array}\right|+\left|\begin{array}{c}
\varepsilon_{1} \\
\varepsilon_{2} \\
\varepsilon_{N}
\end{array}\right|=X \beta+\varepsilon
$$

The climate change adaptation strategies employed by rice farmers to mitigate the effect of climate change include varying land size, sales of crops, and varying planting and harvesting dates; soil and water conservation techniques; and mulching. Other adaptation strategies include the rearing of improved livestock varieties, and mixed cropping, monocropping, use of agrochemicals and no adaptation. The PCA technique was used to reduce the multi-dimensionality of adaptation strategies into an array of case-specific scores defining the strength and shapes of belief in seasonal climate change (Jolliffe 2005). For this study, the first PC with highest loading of $68 \%$ was chosen.

The analytical approach used for the second stage extends the model by Rahm and Huffman (1984) and Adesina and Zinnah (1993) that links farmers' utility to the choice of a given agricultural technology (for this study, adaptation strategy), by adding credit constraints and environmental risk that signify climate change. Decisions are made by the households to maximize their expected utility. Household utility is a function of expected costs and benefits of adopting climate change adaptation strategies as well as their preferences, which are always influenced by various factors. The benefit derived from choosing a strategy may be a stability of productivity with an implicit reduction in the impact of climate change. A utility is maximized by a risk-averse farmer when he chooses a strategy of which the benefits of adaptation minus the cost of adapting are more than the benefits realized without adapting. This study follows the method of Hazell and Norton (1986), where a farmers' utility function is defined as follows:

$$
U_{y}=E_{y}-\alpha \omega_{y}
$$

where $U_{y}$ is the assumed utility from choosing an adaptation strategy $\gamma ; E_{y}$ is the nonstochastic component; $\omega_{y}$ is the disturbance term indicating differences in yields; $\alpha$ is a coefficient that captures the risk aversion of each farmer which would affect the degree of variations in the yields $\omega_{y}$. 


\section{Results and discussion}

\subsection{Dimensions of climate change adaptation strategies by PCA}

The result of principal component analysis (PCA) used to compute the dimension of climate change adaptation strategies is presented in Table 1.

To test the suitability of the data on adaptation strategies for climate change for the PCA, both the Kaiser-Meyer-Olkin (KMO) measure of sampling adequacy and Bartlett's test of sphericity (Dziuban and Shirkey 1974) were used. The value of the KMO test was 0.95 , suggesting that the adequacy of input variables for the PCA was excellent, while the test of the null hypothesis that the correlation matrix was an identity matrix reported a $p$-value $<0.000$, suggesting that there was a relationship between the variables. PCA was therefore a suitable method for the extraction of farmers' adaptation strategies. Table 1 shows the retained principal component (PC) representing the different dimensions of the climate change adaptation strategies employed by smallholder rice farmers in the study area. The PC contributed $69 \%$ to the variation in the data. The dominant PC loadings (0.3 and above) used in the IV-GMM model indicate that rice farmers adopted planting of improved variety, use of agrochemicals, varying planting and harvesting dates, mulching as well as soil and water conservation technique as climate change adaptation strategies.

\subsection{Descriptive statistics of selected variables used in the models}

The descriptive statistics on the distribution of smallholder rice farmers in South-West Nigeria is presented in Table 2.

The results in Table 2 show that household heads' average age and years of education are 47 and 6 years, respectively. On extension access, about 53\% of the respondents have contact with extension agents. Access to credit is a major determinant in

Table 1 Dimensions of climate change adaptation strategies used by rice farmers

\begin{tabular}{lc}
\hline Adaptation strategies & PC loadings \\
\hline Varying land size & 0.2575 \\
Sales of crops & 0.2759 \\
Planting of improved variety & 0.3026 \\
Harvesting & 0.2117 \\
Use of agrochemical & 0.3053 \\
Varying planting and harvesting dates & 0.3006 \\
Mulching & 0.3170 \\
Livestock production & 0.2883 \\
Mixed cropping & 0.2503 \\
Mono-cropping & 0.2855 \\
Soil and water conservation & 0.3201 \\
No adaptation & 0.2533 \\
Eigenvalue 8.2800 & \\
$\%$ of variance $69 \%$ & \\
Numbers of observation 360 & \\
KMO test 0.959 & \\
Barllet's test (P-value) $0.0000^{\text {a }}$ &
\end{tabular}

a Represents significance level at $1 \%$ 
Table 2 Definitions and summary statistics of variables used in the model

\begin{tabular}{|c|c|c|c|}
\hline Variables & Description of variables & Mean & SD \\
\hline \multicolumn{4}{|l|}{ Dependent } \\
\hline PCA index & Improved technology & & \\
\hline Risk-constrained & 1 if $\mathrm{HH}$ head is risk-constrained, 0 otherwise & 0.47 & 0.49 \\
\hline Quantity constrained & 1 if $\mathrm{HH}$ head is quantity-constrained, 0 otherwise & 0.54 & 0.49 \\
\hline Price-constrained & 1 if $\mathrm{HH}$ head is price-constrained, 0 otherwise & 0.37 & 0.48 \\
\hline \multicolumn{4}{|l|}{ Independent } \\
\hline Gender & 1 if $\mathrm{HH}$ head is male and 0 if female & 0.56 & 0.50 \\
\hline Household head's age & Age of HH head (years) & 47.28 & 7.67 \\
\hline Marital status & 1 if $\mathrm{HH}$ head is married, 0 if other/single/widowed & 0.80 & 0.40 \\
\hline Educational status & Years of education of HH head (years spent in school) & 6.45 & 5.70 \\
\hline Household size & Number of HH size (number) & 4.66 & 1.24 \\
\hline Off-farm activities & 1 if $\mathrm{HH}$ engages in any off-farm activity & 0.54 & 0.50 \\
\hline Farming experience & Years of $\mathrm{HH}$ experience in rice production (years) & 15.73 & 5.09 \\
\hline Access to credit & 1 if $\mathrm{HH}$ has access to credit, 0 if otherwise & 0.57 & 0.50 \\
\hline Amount received & Amount of credit received in Naira & $38,630.56$ & 47577.03 \\
\hline Distance to loan source & Distance to the source of loan ( $\mathrm{km})$ & 13.06 & 13.55 \\
\hline Annual interest rate & Annual interest rate (\%) & 0.65 & 0.61 \\
\hline Farm size & Total land owned by HH (hectares) & 7.37 & 3.04 \\
\hline Access to climate info & 1 if $\mathrm{HH}$ climate change information, 0 if otherwise & 0.36 & 0.48 \\
\hline Access to extension & 1 if $\mathrm{HH}$ access to extension, 0 if otherwise & 0.53 & 0.50 \\
\hline Membership & 1 if $\mathrm{HH}$ belongs to Farmers' Association & 0.54 & 0.50 \\
\hline Mean annual temp & Mean of annual temperature $\left({ }^{\circ} \mathrm{C}\right)$ & 27.66 & 0.05 \\
\hline Mean annual ppt & Mean of annual precipitation (mm) & 111.05 & 16.09 \\
\hline Location_Ekiti State & 1 if $\mathrm{HH}$ is from Ekiti, 0 if otherwise & 0.38 & 0.48 \\
\hline Location_Ondo State & 1 if $\mathrm{HH}$ is from Ondo, 0 if otherwise & 0.38 & 0.49 \\
\hline Location_Osun State & 1 if $\mathrm{HH}$ is from Osun, 0 if otherwise & 0.35 & 0.48 \\
\hline
\end{tabular}

choosing adaptation strategies, but only about $57 \%$ of the smallholder rice farmers have access to credit. However, there are clear variations in terms of access to information, for example, about $36 \%$ of the farmers who at least adopted a strategy have access to information related to climate change. About $47 \%$ of the smallholder rice farmers in the study area are risk-constrained, while $37 \%$ of them are price-constrained and $57 \%$ are quantity-constrained. The average farming experience of the farmers in the study area is 15 years. The result is in agreement with Hitayezu et al. (2010), who posited that farmers' perception and efficient response to the economic conditions is directly related to their resource allocation ability, which is subsequently linked to their human capital endowment.

\subsection{Determinants of credit constraints}

As evident by the non-zero cross-correlation coefficients of the estimated equations' error terms, the Breusch-Pagan test of independence of the error terms of SUR models shows that the credit-constraint models are not independent. Hence, the use of SUR is suitable for estimating the three equations than estimating each of the equations independently. Table 3 presents the results of SUR for credit-constrained farmers. 
Table 3 Results of seemingly unrelated regression (SUR) for credit-constrained farmers

\begin{tabular}{|c|c|c|c|c|c|c|}
\hline & \multicolumn{2}{|c|}{ Risk-constrained } & \multicolumn{2}{|c|}{ Quantity-constrained } & \multicolumn{2}{|c|}{ Price-constrained } \\
\hline & Coef. & Std. Err. & Coef. & Std. Err. & Coef. & Std. Err. \\
\hline Distance to credit source & $0.007^{\mathrm{a}}$ & 0.002 & -0.003 & 0.002 & -0.002 & 0.002 \\
\hline Annual interest rate & $0.323^{\mathrm{a}}$ & 0.052 & 0.070 & 0.053 & 0.009 & 0.039 \\
\hline Sources of credit & $-0.370^{b}$ & 0.179 & $-0.364^{b}$ & 0.181 & -0.150 & 0.136 \\
\hline Amount received & $0.004^{\mathrm{a}}$ & 0.001 & 0.000 & 0.000 & 0.000 & 0.000 \\
\hline Access to extension & 0.029 & 0.039 & $0.744^{\mathrm{a}}$ & 0.039 & -0.005 & 0.029 \\
\hline Access to information & $0.088^{c}$ & 0.051 & -0.059 & 0.051 & 0.018 & 0.038 \\
\hline Access to improved variety & $0.398^{b}$ & 0.184 & $0.354^{b}$ & 0.186 & $0.965^{\mathrm{a}}$ & 0.139 \\
\hline Age & $0.007^{\mathrm{a}}$ & 0.002 & 0.002 & 0.003 & $0.006^{\mathrm{a}}$ & 0.002 \\
\hline Gender & 0.028 & 0.037 & -0.034 & 0.038 & -0.030 & 0.028 \\
\hline Marital status & 0.004 & 0.060 & 0.000 & 0.061 & -0.025 & 0.046 \\
\hline Household size & 0.017 & 0.015 & 0.021 & 0.015 & 0.005 & 0.011 \\
\hline Location_Ekiti & 0.003 & 0.041 & 0.023 & 0.042 & $0.056^{\mathrm{b}}$ & 0.031 \\
\hline Location_Osun & -0.051 & 0.041 & $-0.139^{a}$ & 0.041 & 0.000 & 0.031 \\
\hline Constant & -0.369 & 0.142 & 0.015 & 0.143 & -0.251 & 0.107 \\
\hline$R^{2}$ & 0.5294 & & 0.5151 & & 0.7085 & \\
\hline Prob & $0.000^{\mathrm{a}}$ & & $0.000^{\mathrm{a}}$ & & $0.000^{\mathrm{a}}$ & \\
\hline \multicolumn{7}{|c|}{ Breusch-Pagan test: $\mathrm{Chi}^{2}(3)=1047.65>0.000^{\mathrm{a}}$} \\
\hline
\end{tabular}

a, b,c represent significance level at $1 \%, 5 \%$ and $10 \%$, respectively; Location_Ondo was used as the base category

\subsubsection{Household characteristics}

Among the household characteristics, only the age of the farmer is statistically significant and positively related to risk and pricing constraint conditions. This implies that the probability of being risk- and price-constrained increases with the age of farmers. This could plausibly mean that older farmers are more unproductive and the propensity to adopt new technologies is reduced as compared to young farmers. Hence, lending institutions would prefer to grant credit to young farmers (Omonona et al. 2010). Also, in consonance with this result are the findings of Baiyegunhi et al. (2010), who found a positive relationship between age of the household head and credit constraints.

\subsubsection{Access to services}

Access to extension services is statistically significant and positively related to the quantity constraint condition. This implies that the probability of being quantity-constrained increases with farmers contact with extension agents. This result is unexpected and negates most findings that have reported a positive relationship between credit access and extension contacts with farmers (Omonona et al. 2010; Luan et al. 2016). A possible explanation is that credit-constrained farmers may not have sufficient capital to implement innovations disseminated by the extension agents (Amsalu and De Graaff 2007; Awunyo-Vitor et al. 2014). The result is consistent with the findings of Adesina and Zinnah (1993) that extension-farmer interactions and linkages in Africa in disseminating information to farmers have been persistently weak and ineffective. Access to information is positive and statistically significant in influencing the probability of being riskconstrained. This implies that, as the access to climate change information increases, a likelihood exists of smallholder rice farmers being credit-constrained. This is not surprising and could occur because of the inadequacy of extension services in the study 
area. As posited by Oladele and Adu (2003) and supported by the report from the FGD, a dwindling number of extension workers in the study area vis-à-vis inadequate transportation facilities may result in poor extension services, preventing farmers' access to the necessary information on climate change adaptation strategies.

\subsubsection{Location}

According to Danso-Abbeam and Baiyegunhi (2017), there are important socio-cultural variances among regions, which may affect farmers' response to changes in determinants of input use such as credit. Considering the disparity in the geographical location, rice farmers' location in Ekiti State is statistically significant and positively related to pricing constraint conditions. Ekiti State is prone to erratic rainfall, causing extreme events like floods and droughts which have a noticeable adverse impact on rice yields (UNDP 2008). High transaction costs of credit and vulnerability of the location to climate change could be a plausible reason for smallholder rice farmers in the study area being price-constrained. Conversely, the result shows a statistically significant and negative relationship with quantity-constraint conditions for rice farmers located in Osun State. This implies that farmers located in the Osun State have the probability of receiving the amount of credit applied for. This could be attributed to the fact that branches of financing institutions such as the Central Bank of Nigeria (CBN) and the Bank of Agriculture (BOA) are domiciled in the state.

\subsubsection{Transaction costs}

A positive relationship is hypothesized between credit constraints and the interest rate with the outcome of the analysis confirming it. The interest rate is positive and statistically significant in influencing the probability of being risk- and quantity-constrained. This implies that with an increasing interest rate, the probability of being risk- and quantity-constrained also increases. In other words, as the cost of borrowing credit (interest rate) increases, the demand for credit reduces. This result is in consonance with the studies of Olomola and Gyimah-Brempong (2014), who found a positive relationship between credit rationing and interest rate in loan demand and rationing among smallscale farmers in Nigeria.

The coefficient of the amount of credit received is negative and statistically significant in influencing the choice of adaptation strategy to climate change. The characteristics of this credit received shows that the probability of credit-constrained farmers choosing an adaptation strategy decreases as the amount of credit received increases. The plausible explanation for this phenomenon is that adoption of adaptation strategies can be capital-intensive with some demanding investment in new improved planting materials and other technologies. Therefore, in the absence of sufficient credit, it might be difficult for farmers to adopt any adaptation strategy, even when informed on climate change, as they might not be able to purchase the requisite inputs.

The coefficient of distance to the credit source is also positive and statistically significant in influencing the probability of being risk-constrained in the credit market, implying that the longer the distance to the source of credit, the higher the probability of being risk-constrained. The coefficient of credit sources is negative and statistically significant in influencing the probability of being risk-constrained. This implies that rice farmers are 
Table 4 Effect of credit constraints on the choice of adaptation strategies: IV-GMM model

\begin{tabular}{|c|c|c|c|}
\hline Improved technology & Coefficient & Standard error & P-value \\
\hline Access to climate information & 5.502 & 2.014 & $0.006^{\mathrm{a}}$ \\
\hline Predicted credit risk & -4.031 & 1.707 & $0.018^{b}$ \\
\hline Predicted credit price & -0.469 & 1.164 & 0.687 \\
\hline Predicted credit quantity & -0.895 & 1.455 & 0.538 \\
\hline Gender & 0.107 & 0.281 & 0.703 \\
\hline Marital status & -0.954 & 0.491 & $0.052^{c}$ \\
\hline Age & 0.035 & 0.023 & 0.122 \\
\hline Educational status & -0.002 & 0.026 & 0.930 \\
\hline Off-farm income & 4.224 & 0.327 & $0.000^{\mathrm{a}}$ \\
\hline Farm size & 0.025 & 0.059 & 0.676 \\
\hline Prolonged drought & 2.031 & 0.963 & $0.035^{b}$ \\
\hline Incidence of flood & -1.719 & 0.988 & $0.082^{c}$ \\
\hline Annual temp & 2.170 & 2.266 & 0.338 \\
\hline Annul ppt & 0.017 & 0.011 & 0.109 \\
\hline Location_Ekiti & 0.954 & 0.389 & $0.014^{b}$ \\
\hline Location_Osun & 0.100 & 0.375 & 0.799 \\
\hline Constant & -65.403 & 63.026 & 0.299 \\
\hline \multicolumn{4}{|l|}{ Prob $>\mathrm{Chi}^{2}=0.0000$} \\
\hline \multicolumn{4}{|l|}{$R^{2}=0.4335$} \\
\hline \multicolumn{4}{|l|}{ Wald $\operatorname{chi}^{2}(18)=345.32$} \\
\hline \multicolumn{4}{|l|}{$\begin{array}{l}\text { Over-identification test } \\
\text { Sargan test ( } P \text {-value) } 0.995 \\
\text { Exogeneity tests: }(P \text {-value) } \\
\text { Wu-Hausman } F \text {-test } \\
\text { Durbin-Wu-Hausman } \\
\text { Chi-square test } 0.000\end{array}$} \\
\hline
\end{tabular}

less likely to be risk-constrained in the informal lending market, as there are less stringent conditions for securing credit. This, in turn, suggests that farmers who live further away from formal sources are more likely to be risk-constrained compared to those who live closer (Akudugu 2012).

\subsection{Effect of credit constraints on choice of adaptation strategies: IV-GMM Model}

Validating the over-identifying restrictions in the GMM model is revealed by the Sargan test and the excluded instruments are also good predictors of the endogenous explanatory variables as shown by the relevancy $F$-tests, as pointed in Table 4 . The IMR which measures selection bias in the choice of adaptation strategies was found to be significant for the risk-constrained farmers, implying that there is selectivity bias in the choice of climate change adaptation strategies among farmers. Apart from the determinants captured in the model, this signifies that there are other factors of climate change adaptation strategies not captured in the model estimation. In other words, farmers' perceptions of climate change may differ because of the variety of determinants influencing their responses to climate change impact (Table 4). 


\subsubsection{Household characteristics}

Marital status of rice farmers is statistically significant and inversely related to the adoption of climate change adaptation strategies. This implies that the probability of adoption climate change adaptation strategies reduces among the unmarried rice farmers. This could be attributed to the limited access to resources that makes them significantly less productive in contrast to their married counterparts. This is supported by Tiruneh et al. (2001) and Aguilar et al. (2014) that female-headed households in most cases result from divorce, widow or single women. In Nigerian rural farming communities, women manager's role depends on their position in the society, and widows and divorced women are usually marginalized in terms of access to resources (Aguilar et al. 2014).

\subsubsection{Access to services}

Information may improve awareness and attitudes important in framing the projections of farmers towards resource problems and choice of farming activities (Place and Dewees 1999). Access to information on climate change and its related issues exhibit a positive and significant effect on adoption of climate change adaptation strategies. This inferred that making farmers aware of the adverse impact of climate change enhances their adaptive capacity. Similar findings were reported by Deressa et al. (2011) and Asfaw et al. (2016) in Eastern Ethiopia and North-central Ethiopia, respectively. The result from the estimation technique indicates that involvement of smallholder farmers in non-farm activities significantly increases adoption of climate change adaptation strategies farmers employ to mitigate the adverse effects of climate change. The positive impact of nonfarm work on climate change adaptation strategies agrees with the studies of Sallawu et al. (2016) and Deressa et al. (2011) in Nigeria and Ethiopia, respectively. The result suggests that the involvement of farm households in non-farm economic activities may free farmers from financial burdens and credit-constraint conditions, inducing to invest in productivity-enhancing farm inputs and other adaptation strategies to minimize production risk. Deressa et al. (2009) reported that engagement in non-farm income-generation activities enhances the chance of changing planting and harvesting dates, planting trees, and using irrigation systems as mitigation strategies.

\subsubsection{Climate variables}

Increasing climate warming is associated with a reduction in water resources and a high evaporation rate, which increases water scarcity, shortage of food production and other uses (Nhemachena et al. 2014). The only way to mitigate this is through the adoption of different adaptation strategies to climate change (Kurukulasuriya et al. 2006; Deressa et al. 2009 and Apata 2011). Farmers' response to increasing temperature is through the adoption of the use of soil and water conservation adaptation strategies in conserving the little rain received. This could be attributed to the fact that mixed farming systems are diversified, and farmers have several alternative crop options to grow in ensuring that, if one option fails, the other will thrive, even with the incidence of climate change.

Although adaptation partially limited the negative impact of the rainy season's precipitation on net revenue, it did not solve the problem of drought in the dry season. The coefficient of prolonged drought is positive and statistically significant in influencing the choice of adaptation strategy employed. This implies that, as the impact of climate 
change increases because of prolonged drought, the probability of adopting climate change adaptation strategies increases. The reduction in net revenue per household during the wet season is due to the already high level of rainfall during this season, any further increase in precipitation results in extreme weather phenomena such as heavy rainfall, floods and landslides. Surprisingly, the coefficient of flood incidence is negative and statistically significant with the choice of adaptation strategies. It implies that the higher the impact of climate change because of flood incidence, the lower the probability of adopting a choice of adaptation strategies to climate change.

\subsection{Conclusion and policy implications}

The result of the PCA shows the dominant climate change adaptation strategies adopted by the rice farmers, viz. planting of improved variety, use of agrochemicals, varying planting and harvesting dates, mulching as well as soil and water conservation technique. The quantitative analysis from this study points to the fact that age of the household, source of credit, distance to the source of credit, interest rate, access to extension and climate information were the determinants of credit constraint amongst the smallholder rice farmers in South-West Nigeria. Considering the nexus between climatic factors and credit constraints as noted in this study, increasing awareness about how the credit market works and information on the provision of climate change can help farmers to better adapt to climate change. Furthermore, given the links between credit constraints and climatic factors noted in this study, increasing awareness about how the credit market works and the provision of climate information can help farmers to better adapt to climate change. The location of the Ekiti State, which is more vulnerable to climate variability, needs special assistance in order to gain better access to the rural credit market and build its adaptive capacity. This largely significant impact of the credit-constraint category on the adaptation strategies confirms the critical role that credit availability has in adaptation investment. Therefore, in light of the above results, it is recommended that the government frame an agriculture credit policy addressing the issues of smallholder farmers, particularly in areas that are vulnerable to climate change. The government can focus on financial support policies to help smallholder farmers out of the vicious cycles of financial exclusion in order to achieve sustainable development of its rural economy, and improve the livelihood of the farmers. Another recommendation of value is that policies enhancing and strengthening institutional support may also enhance the adaptation capacity of smallholder farmers. A necessary addition should be developed to the assistance already being provided under Nigeria Incentive-Based Risk Sharing System for Agricultural Lending (NIRSAL) in the form of loan guarantees and other risk-sharing incentives, such as a regulatory environment that supports the modern contractual obligations that are characteristic of well-functioning agricultural financing.

\section{Acknowledgements}

We are very grateful to the enumerators and the farmers who seated patiently for hours providing responses to the questionnaire

TOO: application of statistical, mathematical, computational, or other formal techniques to analyse or synthesize study data; LJSB: PhD supervisor, responsible for oversight and leadership responsibility for the research activity planning and execution, including mentorship external to the core team.

Funding

This research did not receive any specific Grant from funding agencies in the public, commercial, or not-for-profit sectors. 


\section{Availability of data and materials}

The data that support the findings of this study can be obtained from the authors upon request

\section{Ethics approval and consent to participate}

The study received an ethical clearance and each participant signed a consent form.

\section{Conflict of interests}

The authors declare that they have no competing interests.

\section{Author details}

1 SAEES (School of Agricultural, Earth and Environmental Sciences), University of KwaZulu-Natal, P. Bag X01 Scottsville, 3209 Pietermaritzburg, South Africa. ${ }^{2}$ Department of Agricultural Economics, Obafemi Awolowo University, Ile-Ife, Nigeria.

Received: 29 October 2019 Revised: 14 February 2020 Accepted: 2 April 2020

Published online: 10 April 2020

\section{References}

Abdulai A, Huffman W (2014) The adoption and impact of soil and water conservation technology: an endogenous switching regression application. Land Econ 90(1):26-43

Adegeye A, Dittoh J (1985) Essentials of agricultural Economics1. Impact Publishers Economics Nigeria Limited, Ibadan

Adesina AA, Zinnah MM (1993) Technology characteristics, farmers' perceptions and adoption decisions: a Tobit model application in Sierra Leone. Agric Econ 9(4):297-311

Agboola SA (1979) An agricultural atlas of Nigeria. Oxford University Press, Oxford

Aguilar A, Carranza E, Goldstein M, Kilic T, Oseni G (2014) Decomposition of gender differentials in agricultural productivity in Ethiopia. Agric Econ 46(3):311-334

Akudugu MA (2012) Estimation of the determinants of credit demand by farmers and supply by rural banks in Ghana's Upper East Region. Asian J Agric Rural Dev 2(2):189-200

Amsalu A, De Graaff J (2007) Determinants of adoption and continued use of stone terraces for soil and water conservation in an Ethiopian highland watershed. Ecol Econ 61:294-302

Apata TG (2011) Effects of global climate change on Nigerian agriculture: an empirical analysis. CBN J Appl Stat 2(1):31-50

Asfaw S, Di Battista F, Lipper L (2016) Agricultural technology adoption under climate change in the Sahel: microevidence from Niger. J Afr Econ 25(5):637-669

Awunyo-Vitor D, Mahama Al-Hassan R, Bruce Sarpong D, Egyir I (2014) Agricultural credit rationing in Ghana: what do formal lenders look for? Agric Financ Rev 74(3):364-378

Ayanlade A, Radeny M, Morton JF (2017) Comparing smallholder farmers' perception of climate change with meteorological data: a case study from southwestern Nigeria. Weather and climate extremes 15:24-33

Baiyegunhi LJS, Fraser GCG, Darroch MAG (2010) Credit constraints and household welfare in the Eastern Cape Province, South Africa. Afr J Agric Res 5(16):2243-2252

Baum CF, Schaffer ME, Stillman S (2003) Instrumental variables and GMM: estimation and testing. Stata J 3(1):1-31

Boucher SR, Carter MR, Guirkinger C (2008) Risk rationing and wealth effects in credit markets: theory and implications for agricultural development. Am J Agr Econ 90(2):409-423

Cochran WG (1977) Sampling techniques, 3rd edn. Wiley, New York, pp 72-74

Danso-Abbeam G, Baiyegunhi LJS (2017) Adoption of agrochemical management practices among smallholder cocoa farmers in Ghana. Afr J Sci Technol Innov Dev 9(6):717-728

Deressa TT, Hassan RM, Ringler C, Alemu T, Yesuf M (2009) Determinants of farmers' choice of adaptation methods to climate change in the Nile Basin of Ethiopia. Glob Environ Change 19(2):248-255

Deressa TT, Hassan RM, Ringler C (2011) Perception of and adaptation to climate change by farmers in the Nile basin of Ethiopia. The Journal of Agricultural Science 149(1):23-31

Dinopoulos E, Kalyvitis S, Katsimi M (2017) Variable export price elasticities and credit constraints: theory and evidence from Greek firms. Unpublished manuscript, University of Florida

Di Falco S, Veronesi M (2013) How can African agriculture adapt to climate change? A counterfactual analysis from Ethiopia. Land Econ 89(4):743-766

Di Falco S, Veronesi M, Yesuf M (2011) Does adaptation to climate change provide food security? A micro-perspective from Ethiopia. Am J Agr Econ 93(3):829-846

Doan, T., J. Gibson, M. Holmes. 2010. What Determines Credit Participation and Credit Constraints of the Poor in Peri-Urban Areas, Vietnam? MPRA (Munich Personal RePEc Archive) Paper No. 27500. Hamilton, New Zealand: Economics Department, University of Waikato

Dorfman, P. W. (1996). International and cross-cultural leadership research. Handbook for International Management Research, 2

Dziuban CD, Shirkey EC (1974) When is a correlation matrix appropriate for factor analysis? Some decision rules. Psychol Bull 81(6):358

Ellis F (2000) Rural livelihoods and diversity in developing countries. Oxford University Press, Oxford

Eswaran M, Kotwal A (1990) Implications of credit constraints for risk behaviour in less developed economies. Oxford Econ Papers 42(2):473-482

Foltz JD (2004) Credit market access and profitability in Tunisian agriculture. Agric Econ 30(3):229-240 
Hazell PBR, Norton RD (1986) Mathematical programming for economic analysis in agriculture. Macmillan, New York, USA, pp 90-95

Hitayezu, P., Okello, J. J., Gor, C. O. 2010. Drivers of Household Participation in the Rural Non-Farm Labor Markets in the Post-War Rwanda. Poster presented at the Agricultural and Applied Economics Association

Holden NM, Brereton AJ, Fealy R, Sweeney J (2003) Possible change in Irish climate and its impact on barley and potato yields. Agric For Meteorol 116(3-4):181-196

Huq S, Reid H, Konate M, Rahman A, Sokona Y, Crick F (2004) Mainstreaming adaptation to climate change in least developed countries (LDCs). Clim Policy 4(1):25-43

Jaffee D (1971) Credit rationing and the commercial loan market. John Wiley \& Sons, New York

Jolliffe I (2005) Principal component analysis. Springer, Berlin

Kassie M, Jaleta M, Shiferaw B, Mmbando F, Mekuria M (2013) Adoption of interrelated sustainable agricultural practices in smallholder systems: evidence from rural Tanzania. Technol Forecast Soc Chang 80(3):525-540

Khantachavana, S. V., Turvey, C. G., Kong, R. 2011. Risk rationing in China rural credit markets. A Selected paper for presentation at the Agricultural and Applied Economics Association 2011 and the Agricultural and Applied Economics Association and Northeastern Agricultural and Resource Economics Association Joint Annual Meeting. Pittsburgh, PA, July (pp 24-26)

Knox J, Hess T, Daccache A, Wheeler T (2012) Climate change impacts on crop productivity in Africa and South Asia. Environ Res Lett 7(3):034032

Leclère D, Jayet PA, de Noblet-Ducoudré N (2013) Farm-level autonomous adaptation of European agricultural supply to climate change. Ecol Econ 87:1-14

Luan DX, Bauer S, Kuhl R (2016) Income Impacts of credit on accessed households in rural Vietnam: do various credit sources perform differently? AGRIS on-line Pap Econ Inform 8(1):57-67

Mulwa C, Marenya P, Rahut DB, Kassie M (2017) Response to climate risks among smallholder farmers in malawi: a multivariate probit assessment of the role of information, household demographics and farm characteristics. Clim Risk Manag 16:208-221

Muniraj R (1987) Farm finance for development. Oxford \& IBH Publishing Company, New Delhi

Ngigi MW, Mueller U, Birner R (2017) Gender differences in climate change adaptation strategies and participation in group-based approaches: an intra-household analysis from rural Kenya. Ecol Econ 138:99-108

Nhemachena C, Hassan R, Chakwizira J (2014) Analysis of determinants of farm-level adaptation measures to climate change in Southern Africa. J Dev Agric Econ 6(5):232-241

Nilakantan R, Datta SC, Sinha P, Datta SK (2013) The impact of microfinance on women empowerment: evidence from Eastern India. Int J Dev Confl 3(1):27-40

Oladele Ol, Adu AO (2003) Constraints to feedback provision on forestry-related technologies. J Agric Soc Res $3(2): 18-41$

Olomola A, Gyimah-Brempong K (2014) Loan Demand and Rationing among SmallScale Farmers in Nigeria. Discussion Paper Series 01403. International Food Policy Research Institute (IFPRI), Washington

Omonona, B. T., Lawal, J. O., Oyinlana, A. O. 2010. Determinants of credit constraint conditions and production efficiency among farming households in Southwestern Nigeria. In: 2010 AAAE Third Conference/AEASA 48th Conference, September 19-23, 2010, Cape Town, South Africa (No. 95775). African Association of Agricultural Economists (AAAE) \& Agricultural Economics Association of South Africa (AEASA)

Petrick JF (2004) The roles of quality, value, and satisfaction in predicting cruise passengers' behavioral intentions. J Travel Res 42(4):397-407

Place F, Dewees P (1999) Policies and incentives for the adoption of improved fallows. Agrofor Syst 47(1-3):323-343

Rahm MR, Huffman WE (1984) The adoption of reduced tillage: the role of human capital and other variables. Am J Agr Econ 66(4):405-413

Sallawu, H., Tanko, L., Coker, A, Sadiq, M (2016) Livelihood and income diversification strategies among rural farm households in Niger State, Nigeria. Asian J Agric Ext Econ Soc. https://doi.org/10.9734/AJAEES/2016/26010

Sarker MAR, Alam K, Gow J (2014) Assessing the effects of climate change on rice yields: an econometric investigation using Bangladeshi panel data. Econ Anal Policy 44(4):405-416

Seo SN (2011) An analysis of public adaptation to climate change using agricultural water schemes in South America. Ecol Econ 70(4):825-834

Tesfahunegn GB, Mekonen K, Tekle A (2016) Farmers' perception on causes, indicators and determinants of climate change in northern Ethiopia: implication for developing adaptation strategies. Appl Geogr 73:1-12

Tiruneh A, Tesfaye T, Mwangi W, Verkuijl H (2001) Gender differentials in agricultural production and decision-making among smallholders in Ada, Lume, and Gimbichu Woredas of the Central Highlands of Ethiopia. Cimmyt

Wooldridge JM (2003) Further results on instrumental variables estimation of average treatment effects in the correlated random coefficient model. Econ Lett 79(2):185-191

\section{Publisher's Note}

Springer Nature remains neutral with regard to jurisdictional claims in published maps and institutional affiliations. 